\title{
Socialisation in Different Socialisation Contexts
}

\subsection{INTRODUCTION}

In the first five chapters, we provided a general outline of the connections between Social Inequality, Childhood and the Mediachildhood (Chapter 2) and discussed the theoretical basis of an approach to socialisation (Chapter 3), which is integrated, praxeological, related to lifeworlds and freighted with methodological consequences for our longitudinal study (Chapter 4). In Chapter 5, we introduced the families of our panel in order to demonstrate how the results of the study arose. In the following chapter, we will present the main results and illustrate their provenance by recalling briefly some relevant theoretical and methodological aspects of our longitudinal study.

According to our integrative approach, as outlined in Chapter 3, socialisation is conceptualised as a contextual, interwoven process, in which the children and the subsequent adolescents constructed the way they live against the background of the specific social situation, in which they grew up, and of their psycho-social development as individuals. Following Ien Ang's understanding of contextualism, we have to analyse the entangled interplay between the different contexts that shaped the children's growing up, for instance, the family, media, peers and educational institutions. In this chapter, we will present our first analytical step, where we describe and discuss the relevance of each context, together with its reflection in the children's everyday lives. As a second step, we

(C) The Author(s) 2019

I. Paus-Hasebrink et al., Social Inequality, Childhood and the Media, Transforming Communications - Studies in Cross-Media Research, https://doi.org/10.1007/978-3-030-02653-0_6 
will focus on the direct interplay of two of these contexts, family and media, and analyse parents' practices in mediating their children's media use (see Chapter 7). Finally, by reconstructing the options for action, outlines for action and competences for action of the families involved, we will analyse how the different contexts are integrated into their everyday lives (see Chapter 8).

The empirical basis for this chapter is what we term the focused analysis of the data collected in twelve years (see Chapter 4). Based on the matrices, we structured thematically for each family across all waves of data collection, we identified and condensed all references to the different contexts. In the following, we will describe these condensed observations and selectively illustrate them by referring to particular children and their families and by quoting (translated) statements from the interviews. We would like to point out that the purpose of this chapter is to highlight the particularities of the families in our sample, who are, as was described in previous chapters, socially disadvantaged. Since there is no data available about a control group from different socio-economic contexts, the goal is not to present the families' particularities as phenomena that would only be found among socially disadvantaged ones. The interpretations that follow below must be seen as observations of phenomena occurring among families in our panel and are not meant to single out certain problems as exclusive among socially disadvantaged individuals. Since for example media play an important role in the life of most young people (see Common Sense Media, 2015, 2017; MPFS, 2017, pp. 6-10 and 13-15; Ofcom, 2017, pp. 21-74; see also Chapter 2), certain phenomena could also occur among non-socially disadvantaged children and adolescents, but, and this is the crucial point, in a family context that is marked by entirely different experiences, opportunities and especially economic and educational circumstances. The aim is thus to highlight the individual dealings with the respective situation of a family and a child in the family, the potential causes for certain actions and interests that were identified and to point out patterns that emerged across our sample.

In this chapter we present our observations about the social connections and social contexts that the young people in our sample experience. Due to the density of the data that was collected over such a long period of time, this has to be understood as a compact overview that builds on the interpretation of a rich stock of data from various qualitative 
methods. A deeper look into this data and the origin of the interpretations will be given in Chapter 8 of this book.

The chapter is structured as follows: the first sub-section focuses on media as context for the children's socialisation. After a general overview of the role of different media within young peoples' media repertoires, we will look back into the role of media extending over preschool and elementary school and into mid-childhood. Then we will analyse the adolescents' patterns of media usage in more detail. We can thus illustrate and reflect upon the interwoven processes of a dynamic media environment and of children's growing up and dealing with relevant developmental tasks in their everyday life. The next sub-section (see Section 6.3) is dedicated to the family as a context for socialisation and sets out the roles of parents and siblings as well as the overall process of doing family. While media and family can be regarded as the key contexts of socialisation for all the children, it became apparent that some other contexts were also very important, at least for some of the children. Section 6.4 on the role of Extra-Familial Socialisation Contexts will deal with Relatives and Friends of the Family (6.4.1), the children's and adolescents' Peers, Friends and Romantic Relationships (6.4.2), Kindergarten, Schools and Apprenticeships (6.4.3), Assisted Living Communities and Apprenticeship Hostels (6.4.4), (Sports)Clubs (6.4.5) and Politics and Society as a whole (6.4.6).

\subsection{Media as a Context for Socialisation}

\subsubsection{The Role of Media, Extending Over Preschool and Elementary School into Mid-Childhood}

Today's socialisation is mediatised socialisation (Paus-Hasebrink \& Bichler, 2008; see also Couldry \& Hepp, 2017, p. 151). This had already become obvious in the first two years of the longitudinal study-the children were five to seven years old. Media were highly relevant at kindergarten age, as well as in the first years of school.

One fundamental outcome during the whole inquiry was noting how the families were quite well equipped with media devices. Thus, the restricted socio-economic background of the families is not reflected in restricted media devices. Media were an integral part of everyday life-for the parents as well as for the children. Especially in the second wave of the survey, with the children entering elementary school, the 
households upgraded massively with new computer equipment. Nearly every family owned a computer with internet access; several children even got their own computers.

In the first wave, when the children were about five years old, their media repertoire included mostly programmes on private television channels and specifically labelled for children. Books were not very common within the families, but if there were some, they were usually linked to cross-media distribution strategies of heroes or stories that appear in different media channels, for example audio-cassettes, video games or movies. During the first wave of the survey, the computer was used for video games at most.

In the second wave-the children were already in school-they were highly interested in early evening programmes for general audiences from private television channels (see Paus-Hasebrink \& Bichler, 2008). Books still did not find much favour, as computers gained more relevance than in the first wave. However, these devices were barely used for educational purposes, although this was the parents' primary intention when buying them. In this wave, violent computer games were part of the everyday life of some boys in the panel, for example, for Timo Landinger, Erich Grubert, Manfred Oblinger and Torsten Kaiser. This was especially the case if the families were quite stressed anyway. In the second wave in 2007 , it was striking that, for most of the boys, the computer was already their favourite device, and online computer games were among their favourite media. The internet was not important at all during that time. Today, due to the rapid diffusion of tablets and smartphones, the situation would certainly be quite different among children at a comparable age.

By the same token, television played a specially important role (see Paus-Hasebrink \& Bichler, 2008; see, as well, research from for example, Grüninger \& Lindemann, 2000; d'Haenens, 2001; Roberts \& Foehr, 2004; Rideout \& Hamel, 2006; Rideout, Vandewater, \& Wartella, 2003; Woodard \& Gridina, 2000). We can assume that this would no longer be the situation today, when even younger children use tablets or smartphones quite early (see, for example, MPFS, 2014, pp. 5-7; Chaudron et al., 2015; Education Group, 2016; MPFS 2016, pp. 29-30; see Chapter 2). At that time, our children experienced their favourite television series, particularly those offered by private channels, as reliable companions (compare, for example, Feierabend \& Scolari, 2018, pp. 169-170 and 174). They were searching for series providing orientation and 
stability or even a solid structure for their recreational time, which they often perceived as empty. For instance, Olivia Fein assigned her favourite cartoon characters as her "best friends". Against the background of her particularly stressful life-situation, her media use can be interpreted as flight into a media-based fantasy world. Among the boys, cartoon series and especially anime series with a strong hero like Herkules, Dragonball (Z), Yu-Gi-Oh!, Tom and Jerry, Pokémon, Tarzan or One Piece were preferred. These stories are very exciting, and their protagonists are strong and courageous, as they have to engage in fights and duels.

By contrast, the girls tended towards female protagonists engaged with everyday topics, like Kim Possible, Bibi Blocksberg, a highly favoured German cartoon with a strong girl in the centre of the story, or Charmed and Sabrina and, a while later, Hannah Montana. Besides that, they liked anthropomorphic animal figures, for example Spongebob or Benjamin Blümchen, by then a very popular cartoon series in Germany and Austria. When the girls grew older, they also liked daily soaps.

During the third wave of the survey-the children were about ten years old by then-the usage of computers and the internet was increasing, even though television retained its relevance. Computer games, like free browser and social games, but also online multiplayer role gamesoften, according to the official national classification of media content, only suitable for sixteen-, or even eighteen-, year-olds-were notably popular among the boys, for example, Call of Duty 3 \& 4 (recommend for people older than 18 years), Super Mario, Super Mario Galaxy, Mario Kart, Animal Crossing (versions recommended for adolescents older than 16), Naruto, Skyrim (for people over 18) and so on. The girls preferred so-called simulation games. It is noticeable that the children were hardly interested in social networking sites at that time. The boys, but, above all, the girls, used audio media mainly for current pop and rock music.

The relevance of Facebook, Messengers and YouTube for the elevento twelve-year-olds increased distinctly during the fourth wave of the survey. About half of the children were using such media services. Along with computer games, communicating with friends became certainly more relevant, especially among the girls. A few of the adolescents were not allowed to join Facebook at this time, others voluntarily abstained. Television maintained its status as a reliable partner in everyday life. Whether it was computers, television or internet usage, the media repertoire of the boys and girls was primarily based on entertainment. They 
occasionally used the internet for educational purposes, but beyond that, any search for information was rarely intentional.

As regards television, the children were now using programmes for general audiences, mainly on private channels. As they grew older, daily soaps ceased being a favourite with them. The girls mostly favoured casting shows, for example, Deutschland sucht den Superstar, the German version of Pop Idol. The boys liked international series, like Scrubs, Two and a Half Men and How I Met Your Mother. In Austria, all these international formats are broadcast with German dubbing. Where they did watch cartoons, the boys liked action-stories, like Naruto, Superman and so on. They preferred comedy series, reality TV, casting shows and crime series. The girls chose series with a strong girl as the focus. These findings concerning the preferred content on TV are comparable to the results of nation-wide representative studies (see, for example, Ofcom, 2017, pp. 297-298; MPFS, 2017, p. 41).

Across the first four waves of data collection, it was very noticeable that parents and their children gave quite different answers and statements on the children's most favoured media content and media protagonists, especially when the children were going to kindergarten or to school. In the first waves of research, this mostly applied to the usage of television. In this case, the parents' and the children's answers differed greatly over the programmes' transmission times and, when children grew older, over the length of their television usage as well. Most parents expressed wishful thinking by quite often naming programmes, which did not seem violent or full of strong visual effects. They were aware of the public discourse on the media usage appropriate to children and adolescents (see Chapter 7). As the boys grew older, parents mostly were concerned that boys might use pornography or hard-core media content. As for the girls, they did not mention disliked media content as often. All in all, parents ceased to care about the public debates on appropriate media content for older children.

At this point, we offer a short interim conclusion: similarly to other young people, our children assigned media different functions according to their personal needs and concerns. Some children deliberately watched television to escape from boredom and to structure their everyday lives. Furthermore, they used television and the characters shown there as an orientation and were, in fact looking for virtual mentors, usually in the form of strong characters of their own gender. 


\subsubsection{The Role of Media in the Phase of Adolescence}

We examined the phase of adolescence during the fifth and the sixth waves of our study (2014 and 2016). During this important phase of their youth, the essential developmental tasks for our adolescents (see Havighurst, 1972; Tarrant, MacKenzie, \& Hewitt, 2006), for example, developing their identity, finding the means of understanding their identity by learning to present and position themselves socially, participating in different peer groups and in society at large, and distancing themselves from their parents. In order to cope with these tasks, the adolescents developed new codes and forms of verbal expression or used other media than that used by their parents (see MPFS, 2017, pp. 32-38). As with other adolescents (see Paus-Hasebrink, Schmidt, \& Hasebrink, 2011; Paus-Hasebrink, Wijnen, \& Brüssel, 2011), the young people in our panel used social media applications intensively, for example message boards to test und present themselves as a form of game playing, to maintain their relationships to friends and, in a few cases, to establish their first romantic bonds. These practices can be conceptualised as advanced, media-related forms of identity management, relationship management and information management (see Paus-Hasebrink et al., 2011 , p. 27):

- Identity management connotes accessing specific aspects of character, like certain experiences. Furthermore, there is a fashioning of the self, motivated by a visual presence (for example, pictures, videos) on social media.

- Relationship management is basically about every relationship, but rather more specifically about maintaining or gaining friendship.

- Information management is about selecting, channelling and filtering every kind of information, for example, research within Wikipedia.

To develop this general observation on social media use, we will now condense and interpret our data regarding the particular roles of different media for adolescents.

\subsubsection{Smartphones as the New Access to the World}

For most of our subjects, smartphones played a vital role (see, for example, Lauricella, Cingel, Blackwell, Wartella, \& Conway, 2014; MPFS, 2017, pp. 13-15 and pp. 26-29; see Chapter 2). Norbert Zarbl put it 
the following way: "Without a smartphone, nothing will get done". ${ }^{1}$ More than half of the adolescents in our panel favoured smartphones and, above all, WhatsApp. These results correspond with results from MPFS (2017, pp. 27-29 and 33-36) and Education Group (2016). The adolescents liked WhatsApp mostly because this service is free of charge - in contrast to texting (regarding the importance of messenger applications and more particularly of WhatsApp among adolescents, see Koch \& Frees, 2017, p. 445; Ofcom, 2017, pp. 104-105).

\subsubsection{New Audiovisual Services as Means for Interactive Entertainment} Among the adolescents of our panel, the video platform, YouTube, proved to be more important than television. As many of them described it, this media service meets their needs and interests particularly well. In this respect, a gender difference becomes apparent: while the girls within the panel chose content with a focus on beauty and styling topics, the boys were more interested in videos about computer and video games (for example, 'Let's Play'-videos). However, regular television was still important. Either it was used as a sort of secondary medium, as the adolescents were concurrently using mobile phones or playing computer games, or it was specifically used for watching entertainment shows, crime stories or sportscasts. In order to satisfy more specific individual needs and compose their own audiovisual repertoire, the adolescents used streaming services, YouTube and pay television like Sky and Sky Go, but also platforms like Burning Series, kinox.to or Naruto-Tube that are regarded as illegal. Concerning the diversity of streaming offerings used by adolescents, we find comparable findings in nation-wide representative studies (see MPFS, 2017, p. 42; Ofcom, 2017, pp. 29 and 74-81), though the profound insights concerning the usage of alternative applications or such that are regarded as illegal are unique results of the qualitative panel study at hand.

\subsubsection{Print Media as Marginal Elements of Adolescents' Media Repertoires}

Reading books, newspapers or magazines was not a habit with most adolescents in our panel, at this point we consider large differences compared to other young people of this age (see, for example, MPFS, 2017, pp. 13-14 and 18-21). A remarkable exception was Gudrun Dornbacher, who regularly read books and newspapers and also wrote her own short stories (see Chapter 8). Compared to her, only a few 
adolescents mentioned print media: Mario Hirtner related how his mother sometimes used to buy a newspaper; Manfred Oblinger stated that his parents took a tabloid newspaper, but it remained unclear if the two boys were themselves interested in newspapers. Benedikt Holzner was the only one to read a newspaper in his family, while Viktoria Öllinger browsed her mother's newspapers on a regular basis. Thus, most adolescents, primarily boys, favoured online games, game consoles and a, more or less, broad variety of social media services over printed media as their individually compiled repertoires.

\subsubsection{Media Protagonists as Guides to Desired Success and Financial Independence}

Media stars, especially YouTube-Stars, were regarded as role models, and for some of the girls and boys so called influencers were highly relevant (see also Ofcom, 2017, pp. 93-94; MPFS, 2017, pp. 44-45). They were admired as examples for social advancement and for being heard by society because of their symbolic and financial success, an opinion some of the panel's adolescents stressed. The children displaying this pattern might see them as role models for financial independence and material security. Among the boys, particularly YouTubers who present games, rankings and tips for online gaming were considered popular. Some of them seemed to see different male YouTubers as reference characters, most likely because they embody success, are humorous and influential, and, consequently, famous. Some of them wished to become YouTubers themselves, like Manfred Oblinger: "This is my dream, to be a YouTuber one day" (Interview, sixth panel wave 2016).

The girls favoured popular female stars and celebrities, and especially during puberty, these female YouTubers served as role models on topics like beauty and styling and provided opportunities to deal with topics that were important to the girls. ${ }^{2}$ In these videos, they found information on, for example, how to present themselves as girls or young women, information their mothers maybe could not, or would not, pass on to them. That some of the girls, like Olivia Fein, lack their mothers' support became clear in the interviews, in one case, Ms. Fein herself repeats her daughter's reproach after she was not able to give her a satisfying answer with regard to her beginning menstrual cycle:

When, when she started having her period, it was pure horror. She got it in winter. She has very severe cramps and always gets mad, because she asks 
me 'How was it when you got yours?' and I just told her that I never experienced pain $[\ldots]$ and I told her how it was for me, that I can't really help her the way she needs it and she just said 'What kind of mother are you? You can't even help me as a mum!' I just told her to go and ask her grandmother. (Interview, sixth panel wave, 2016)

\subsubsection{Social Media Practices as a Symbolic Expression of Individual Spaces}

Media services like WhatsApp or Snapchat were primarily seen as a possibility to create individual spaces independent of their parents' communicative practices. Boys used these services to exchange information or videos about computer games. While joking about topics within this community, they permanently checked their position in the peer group. Girls were most likely to chat on social networking sites like Facebook or to share pictures on Instagram. WhatsApp was used for exchanging videos and especially for voice mails. In contrast to the boys, the girls used media services to communicate with their female friends, and especially their best friends, about problems. They tried to give advice, to gain acknowledgement and affirmation of their image from their friends. They used WhatsApp particularly, as it shaped their friendships with peers and communicated their emotional support during difficult times of life. Some girls used social media as a sort of public diary, within which they recorded the highlights of their everyday day life while waiting for their followers to like and acknowledge their postings. Sometimes WhatsApp or Snapchat were merely used for questions, about what to wear, for instance. However, we can conclude that social media services and applications are now a vital part of the everyday life of adolescents.

\subsubsection{Computer Games as an Expression of Problems Within the Boys' Lifeworlds, but also as a Possibility to Gain Different Kinds of Experience}

Many boys from the panel, like Timo Landinger, Manfred Oblinger, Mario Hirtner, Torsten Kaiser and Alfons Weiss, who belong to families with massive socio-emotional problems, referred overwhelmingly to firstperson-shooter and battle games, like League of Legends, Call of Duty, Grand Theft Auto (GTA) and World of Warcraft. Of course, these games are very popular among boys and young men in general (see MPFS, 2017, pp. 48-51; Ofcom, 2017, pp. 108-112), what was extremely particular about these boys in our sample, however, was that they lacked a 
socially fulfilled life beyond the world of (online) media (on this aspect see also Li, Hietajärvi, Palonen, Salmela-Aro, \& Hakkarainen, 2017). Mario Hirtner and more particularly Manfred Oblinger were exposed to a wide range of experiences playing online games. But in consequence, there are achievements which should not be ignored: The technical knowledge and the abilities mediated through online gaming, hacks, cheats and exchanges with other gamers-in their own country as well as in other countries-meant that they were able to advance to an apprenticeship within the IT industry.

Against the background of their lifeworld (see Chapter 8 for examples and more detailed elaborations), the crucial importance of computer games for these boys can be explained by the following specific functions:

- Compensation for a lack of stimulation: The boys used computer games because of the lack of other possibilities and to compensate the emotional or actual absence of their parents to fill their time with an activity which is particularly important to them, which they find fun and which creates a means of escape from their constrained reality. Timo Landinger is one example, he always expressed his wishes to do more things together with his family, like trips and activities on weekends, but none of the family members ever wanted to do anything like that with him, in general, he felt that no one in the family liked him:

Interviewer: Would you like to spend more time with your mum and dad, can you talk to them about problems?

Timo: [No reaction, keeps playing the video game]

Interviewer: Or is that difficult?

Timo: Hm...difficult.

Interviewer: Why?

Timo: No one talks to me, no one asks me 'What do you wanna do?' Because they don't like me.

Interviewer: They don't like you?

Timo: [Nods] I don't think they do. (Interview in 2012)

His parents saw video games as better leisure-time activities, it seemed that they enjoyed that Timo left them alone when he was in his room all day long, playing games. For Timo, as well as other boys from the sample, these games came to provide a familiar, reliable and comfortable 
environment that they otherwise lacked. The boys did not perceive the time spent on computer games as empty, but rather as an enrichment of their everyday lives.

- Distinction and competition: In their world of game playing, the boys were successful and could, therefore, gain acknowledgement. In socio-emotionally stressed families, this was the only way they got this kind of approval. Game playing provided a safe environment, where they could compete and prove themselves to other adolescents. Due to their involvement and their highly developed skills and competences, some of them were able to keep up with and even overtake their contemporary competitors.

- Experiencing self-efficacy: Online games provide the chance to solve individual tasks satisfactorily and to face risky challenges within an online world-all without the danger of failure in the real world.

- Experiencing companionship: In some cases, the adolescent boys, like Manfred Oblinger, Mario Hirtner and Torsten Kaiser, could not build stable relationships to their peers, felt themselves to be mavericks and maintained few contacts beyond their online environment. When Manfred Oblinger was younger for example, his mother did not approve of the neighbour's children (many with migration backgrounds), claiming that they were a bad influence (2005 and 2007) up to the point where Manfred would try to sneak out to see other children. In order to compensate him for the lack of social contact, Manfred's mother encouraged him to play video games and bought games for grown-ups because he was interested in them more than in children's games: "I keep saying, he needs something, since he doesn't have any friends. I can't produce a friend out of thin air if there is no one. I can't. That's why I think, just let him.” (2007)

Yet, through their abilities in online game playing, Manfred and some of the other boys in the sample cooperated with other gamers and socialised within this online space. This enabled them to deal with their developmental tasks virtually. Contacts with other committed peers contained the chance to talk about technical questions as well as about new strategies to cope with the challenges of online game playing. Manfred Oblinger enjoyed helping his online companions to deal with technical problems and to find new ways of achieving their game-playing goals. 
- Dealing with frustration and aggression: The frequent frustrations in the everyday lives of the adolescent boys often resulted in aggression, especially for those who lived in generally aggressive families. The boys could not live out their aggressions within the family, so the computer games served to vent the frustration in their lives. Timo Landinger serves as one prominent example to illustrate this. When he was still in elementary school, he always wanted to be one of the Pokémon from his favourite games, because, as he hinted at in an interview in 2007, he would hurt his family and shoot at his peers in school so that they would be afraid of him and start to respect him.

The boys' playing especially violent computer games from a firstperson-shooter perspective was generally not really approved by the parents, with exception of Timo Landinger, and during the first and second wave of the survey, Manfred Oblinger. Unlike their everyday life, the only possible negative consequences for them within this virtual world were to lose and, therefore, to be angry about that. Normally, this anger was over their own lacking competence or their bad luck. Both perspectives fed the desire to start again and to do better the next time.

Overall, we can conclude that, even during their adolescence, the boys and girls perceived relevant media content as an important-but not the only-source of information and orientation to cope with their everyday lives. So media were used after long days at school or at work to maintain the relationship with close friends or with a partner. Most of the adolescents had habitually used the media since childhood to satisfy different needs. Hence, it seemed likely that they would turn to media while going through challenging times at school or when starting their apprenticeship. With a preference for content that was entertaining, they suceeded in distracting themselves, at least short time, from their burdens of everyday living.

\subsubsection{Conclusion}

In terms of media content, the findings presented above show that media fulfilled different functions in the everyday life of our children. These functions are narrowly linked to their developmental tasks as well as to the various experiences the panel members underwent throughout their 
childhood and adolescence. When children were confronted with severe emotional experiences, for example the family being torn apart, they particularly tended to engage with certain characters within the media. In this way, they were looking for a supportive counterpart for comfort and to give them an individual sense of safety. Television was primarily a cheap, and, therefore, accessible way to spend some time together, because the families' financial problems precluded any other possibility. In general, throughout their socialisation, the media served in a variety of ways as window to the world, through which to both perceive and be perceived.

Accordingly, we noted that the media became particularly relevant in the children's lives if there were conflicts within the family. This especially happened when parents were not able to maintain certain living standards because they had to deal with their own problems and challenges in their daily routine. As a consequence, they neglected their children and could not manage to support them properly in coping with their developmental tasks. In this case, the young people preferred media content and media services, which seemed suitable for their particular situation. Hence, micro-structural factors, like age and gender, specific developmental tasks and also the children's specific Eigensinn (self-will), all influenced their media usage.

\subsection{The Family as Socialisation Context}

Our study shows that socialisation research must be family research. It indicates that the family is the primary and essential context if children's socialisation is to be sustainable. In this respect, Larson (2006) highlights the role of perceptive, supportive and caring adults in young peoples' growing up, for example, in inculcating motivation and engagement (see as well Rogers Hollifield \& Jewsbury Conger, 2014). Furthermore, Notten and Kraaykamp (2009, p. 185) stress that "parental media guidance takes place less frequently in families that have experienced a divorce and in larger families". But how the parents dealt with their children and how media accompanied the individual development in children were determined by the specific interplay of the parents' $o p$ tions for action, outlines for action and competences for action. Their individual emotional patterns, like affection, or, by contrast, neglect, refusal and even aggression shaped the way the children learned how to deal with everyday challenges in life and, in this context, with available 
media. Over the years of our research, it became manifest that parental disinterest in their children's own concerns, anxieties and wishes, and, closely linked with this, in their media usage as well, had significant consequences for the children. In some cases, these were even traumatising experiences, as with, for example, Timo Landinger, Mario Hirtner and Alfons Weiss, all of whom had to cope with a strong sense of being alone. But we also recognised excessive control over the children's contact with media-among the Rohringer family - as a signal for the parents' lack of trust in their children. These factors interfered with the children's meeting the challenge of building their own competences for action. In another case, an excessive wish for closeness was experienced as terrifying by Viktoria Öllinger and became an impediment to socialisation. The example of her family is notable for the mother-daughter relationship displaying ongoing processes of "parentification", a reversal of roles involving the daughter, "taking on both emotional and functional responsibilities that typically are performed by the parent" (Engelhardt, 2012 , p. 45). Viktoria cared for her ill mother and coped with all challenges of organising their everyday life. So, for Viktoria, there was not enough space to develop her own interests through using media; she suffered from an eating disorder and behavioural problems.

Even though we should not assume that there is a direct, or even causally determined, impact by the media on socialisation, it is likely that they become more important if adolescents' socialisation is shaped by a complicated family context and if the parents are not able to give their children enough attention to make them feel safe and comfortable. ${ }^{3}$ The children in our study who experienced security and emotional closeness were less likely to be overwhelmed by the challenges of their everyday lives. This outcome applied to their dealings with developmental tasks and their coping with family structures or their media usage. These children were developing ambitious outlines for action, for example, concerning apprenticeships, and were establishing their competences for action, in contrast to the adolescents who were not comfortable within their family and hence had to deal with various tasks, including their media usage, on their own.

These circumstances were especially pronounced in families where the adolescents had brothers or sisters and were affected by their relationship to siblings. Schmidt (2014), for instance, has analysed the relevance of siblings for the social and cognitive development of children and adolescents. Feinberg, Sakuma, Hostetler and McHale (2013) have 
demonstrated the role of siblings for well-being, and the research by Rogers Hollifield and Jewsbury Conger (2014) has also shown the significant influence of siblings on adolescents and young adults. On media usage, it became clear to us that older siblings often acted as a guide or role model regarding the choice of media. The younger siblings would adopt the media preferred by the older ones ${ }^{4}$ and talk more intensely and closely about media with siblings than with parents. Especially during the first waves, the younger children asked their older siblings for help. The older sisters and brothers were able to guide and support the younger siblings and were, as with Amelie Aufbauer, guided themselves not only in their own media usage but were also providers for the younger children, for example, by making breakfast, if the parents could not deal adequately with these kinds of tasks because of external pressures, as, for example in the Kaiser, Hirtner, Landinger, Oblinger and Weiss families. In the case of the Ebner family, the parents were not able to use computers; the Stab and Aufbauer families had the same problem when their children were younger, but later on the parents too showed more competence. In general, older and also younger siblings were often more familiar with the media usage of their siblings than their parents; during the interviews with Mrs. Holzner and Mrs. Weiss, the brothers were occasionally present and were better informed than the parents.

Research on the role of siblings states that the relationships between siblings are strongly shaped by how parents interact with their children. In addition to the emotional quality of the siblings' relationship, the individual nature of any child, and also the constellation of siblings (see an overview in Schmidt, 2014), as well as the parents' behaviour as educators all play an important role. We confirmed what Schmidt (2014) has summarised in her overview: "A positive parental behaviour of the parents promotes a positive behaviour in the siblings relationship". But if the parents' behaviour tended to be dismissive, as with the Landinger family, the siblings were more likely to display bad behaviour among themselves. In the Landinger family's case, a bad emotional situation impinged on the youngest brother, Timo (see case description for Timo Landinger in Chapter 5). He felt disregarded by his older siblings and reacted acutely to his parents' behaviour, particularly that of his father. Furthermore, individual discrimination against the children - a child being, generally speaking, disregarded or, by contrast, favoured-played an important role for the children. If a mother 
or a father favoured a child who was brought into the family with a new partner, as in the case of Benedikt Holzner or Alfons Weiss, the parents' behaviour translated into a tense but also apathetic interaction with their other children. They retained less attention than their (half-)siblings and were sometimes severely neglected. The preferred children were less notable for their media usage than their siblings, who had a fraught relationship with their parents. This was the case with the brother of Simone Stab.

Within the scope of this study, it also appeared that some parents could not avoid focusing conflicts on only one child. This might have been caused by their lack of socio-emotional capacities, sometimes accompanied by their restricted housing situation limiting the space available for parents and siblings themselves. In this particular case, temporary accommodation out of the family (see Chapters 5 and 8 ), or a sibling moving out, led to a less tense socio-emotional relationship in doing family. However, although Mrs. Stab did manage to build up an extraordinary relationship with her daughter, Simone, she could not, as a financially challenged single mother, care for her son equally. After severe conflicts because of the son's excessive game playing, Mrs. Stab decided to put him in a socio-pedagogical institution during the week. The situation within the family then eased, fewer conflicts were likely to happen, and the son himself actually coped better when he was back for weekends. Mrs. Stab struggled in her life as a single mother. She acknowledged that she was not able to care for both children equally without a partner. For the Aufbauer family, the oldest sister moving out led to a more comfortable family climate and better core relationships. Before that, the single mother could not afford an adequate flat, so the whole family suffered recurring conflicts because of the different needs of the children. The oldest sister-20 years old during the sixth wave of the survey-had a completely different daily routine to her significantly younger siblings (16-, ten- and one-year old). She was highly stressed by them when she had to deal with different tasks. Conversely, there were conflicts within the family, for example when the older sister wanted to listen to loud music, but for her younger siblings it was bedtime. After her move, the younger siblings got their own room, and the family climate improved significantly, because they had more room overall, and the younger children could live out their own wishes and ideas better. 


\subsection{Extra-Familial Socialisation Contexts}

Besides the families, extra-familial contexts, such as kindergarten or school alongside friends and peer groups, also played a major role in the adolescents' socialisation and grew in importance over the years. In contrast to early childhood and mid-childhood, the dominance of the family decreased as the scope of the children's living environment increased and they explored new micro-systems.

\subsubsection{Relatives and Friends of the Family}

Relatives, and especially grandparents, played a relevant role for many families. They weren't only helping the family with a range of issues but supported them financially as well. Mrs. Weiss inherited real estate and didn't have to work anymore, as the rental income provided a living for her children and herself.

The children were often supported by their grandparents as important caregivers in their everyday life, for example, by giving the children pocket money when the parents could not afford it, as with Mrs. Aufbauer, a single parent. Occasionally, the grandparents or relatives gave presents in the form of media devices like laptops or smartphones. The grandparents, aunts and uncles not only helped to improve the financial situation of the families but also offered educational help or saw to their grandchildren's welfare while the parents were over-challenged (with respect to research on aunts, see May \& Lahad, 2018). Olivia Fein identified her grandmother as an important person in her life and would even discuss puberty problems (during the fifth wave of the survey) with her. Her mother did not have either time for the concerns of her daughter or any interest in them. After Olivia in 2008 threatened to fall down the stairs in school on purpose, while behaving aggressively towards the other children, her grandmother, together with the school principal, approached the child protection services to initiate an examination of the domestic circumstances. After that, Olivia was taken into an assisted living community, where adolescents of different ages were living together and receiving therapeutic treatment. During that time, she visited her family only every second weekend. For Elisabeth Ebner, her aunt was the most important companion in her everyday life. Her parents did not have enough time because there was so much work on their farm, so Elisabeth spent a lot of time with her aunt, who became her 
most important confidante. In the same vein, the aunt intervened in the Pfortner family and mediated a conflict caused by the seemingly extraordinary alcohol consumption of the father. In the case of Alfons Weiss, his uncle paid for the boy's cell phone contract without his mother knowing. For Torsten Kaiser, his grandparents were very important, although his mother was concerned about the contact to the paternal grandfather, as he allowed Torsten to play games she found inappropriate.

However many families lacked any good connection to their relatives. Families with meagre resources - financially and temporally-would have particularly profited, either through the grandparents supervising their children or supporting the family through money. Some of the families were socially isolated generally, because they were not able to build up and maintain close connections to other families or relatives. Mrs. Öllinger, who grew up with foster parents, was supported by them to a certain extent, although the connection was quite loose. As the family lacked regular contact with friends and relatives, Mrs. Öllinger and her daughter were glad to find the mother's biological brother, unknown until then, during the sixth wave of survey. Mrs. Öllinger immediately contacted her brother and sister. The mother and daughter established relations at least with a sister, or respectively aunt, to the family's benefit. During her socio-economic and health crisis, every such contact made her happy.

\subsubsection{Peers, Friends and Romantic Relationships}

In the context of identity formation, especially in middle childhood and adolescence, peers are of prime importance, but also when it comes to questions and the need for help, peers are highly relevant (see Packer, 2017, pp. 487-493). "Considering the social relationship between child and adult to be contradictive, among their peers, the children are the creators and innovators of their own world. We may therefore regard children as mediators between different worlds" (Lillehammer, 2010, p. 10). Contacts with peers means (Youniss, 1980) that children have a particular opportunity to form relationships with other children on an equal and mutual basis, whereas their relationships to adults are characterised by an authority gradient. The interaction between children serves as an impulse to further developmental steps and to engage with the concomitant tasks. Furthermore, a child's issue with identity-potentially prevalent, according to Erikson, at any time during the developmental 
process - can be handled on a different, egalitarian basis during the exercise of self-perception in peer relationships. Self-perceptions can be tested; emotions can be integrated into self-awareness and self-control (cf. Krappmann, 1991, pp. 373f.). As Grundmann states: "Thus, in a group of coevals, individual interests have to be negotiated, and the skills of every individual have to be validated" (Grundmann, 2000, p. 96, translated by the authors).

It was noticeable during the first waves of the survey that the children met their friends outside of the institutional education and support facilities only infrequently, if they were not living in the same neighbourhood or the same region. One reason is that the parents did not really support their children in maintaining friendships. Sometimes, remote housing situations, due to high rents within city areas, were the main reason for the girls and boys living nearly isolated from others, apart from visiting kindergarten and school. ${ }^{5}$ Either there were no children living in their area, or the parents forbade their children to get in contact with other girls and boys from families in any neighbourhood with a migration background (for example, Manfred Oblinger, who got violent computer games for sixteen- to eighteen-year-olds from his mother as compensation). In this context, the residential environment of the family became hugely important. The socio-economically less resourced families were often living in housing areas with a high ratio of immigrants, so to play with peers, the children were dependent on the neighbours' children. Since several parents were afraid that children with a migrant background might have a negative impact on their own children, they tried to block every kind of contact or friendship with children from their neighbourhood. Thus, these children had to suffer from a lack of contacts to peers and friends, while others, who had the opportunity to establish and maintain friendships, stressed their importance. As Benedikt Holzner memorably puts it during the second wave of the study: "Because I like them, and they can explain anything to me". Peers had been the most relevant persons to him for information and exchange about the world.

Across all our waves of enquiry, we noted the media serving as important facilitators of peer relationships. During kindergarten, the media were, as yet, barely relevant for children in their peer context. They usually used the media alone or accompanied by siblings or parents. Stories shown through media were at best re-enacted with coevals (for example, stories and actions from Dragon Ball Z, Lilo and Stitch, Disney's Adventures of the Gummi Bears or Pumba Bear). Two years later, 
a more collective way of using media became common, indicating that the importance of media within the peer group had risen. During the period of elementary school, the children used media-mostly computers, but also game consoles, television and radio-together with friends or classmates.

According to Reitz et al., "when boys and girls grow older their attention shifts from parents to peers, thus peers become a core influence for their development" (Reitz, Zimmermann, Hutemann, Sprecht, \& Neyer, 2014, p. 281; see also Harter, 2012). Accordingly the boys of our panel mainly focused on playing computer games together, and the girls preferred to go to the movies or sometimes read some girls' magazines together. As children moved through school and later changed schools during the third and fourth wave of the survey, peers in general, and friends in particular, became more important for the adolescents. As Morgan states, "developing a meaningful sense of one's sexual orientation and identity is an important undertaking during emerging adulthood" (Morgan, 2012, p. 52). Hence, romantic partnerships also became more relevant for the adolescents. Now they were using media services like Skype, MSN, other chat services and even Facebook, to maintain their contacts.

During the last two waves of the survey, it appeared that children from families that suffered under particular socio-economic and socio-emotional challenges and had severe problems with doing family, were not able to utilise their increased mobility and capacity for communication. For them, there was no social security net available from relatives or friends of the families. The adolescents, mainly boys, had problems keeping up with peers in their individual development, so they often felt like mavericks in class. Either they had no friends, or just a few, with whom they shared their interests. Their friendships were primarily based around their online games. The girls did not depend on such online contacts. Viktoria Öllinger, Olivia Fein and Isabelle Rohringer had at least one good friend to talk with about their problems. Tarrant et al. (2006) point out the narrow relationship between adolescents' objective position in a peer network and indicators of social competence, including loneliness, depression, aggression and a general self-concept (Tarrant et al., 2006). Against this background, it is not surprising that adolescents, like Manfred Oblinger, Timo Landinger and Viktoria Öllinger, all of whom faced considerable challenges in their families and had difficulties dealing with restricted relationships, had not 
bonded with someone in a romantic relationship yet. Olivia Fein was the only one consistently seeking confirmation of her identity from males.

Other adolescents in our panel deemed face-to-face-relationships more important than mediated recreational time. They certainly used computer games and were interested in other (media-related) activities, but these were not a basis for leisure time, whereas immediate contact to friends was by far more important to them. At this time, some of these adolescents also experienced first romantic relationships, and some were able to maintain a relationship for quite a long time.

\subsubsection{Kindergarten, School and Apprenticeship}

The time in kindergarten, and later also in school, played an important role in the children's everyday lives. During the first two waves of the survey, parents delegated a great amount of responsibility for the children to kindergarten and schools. Single mothers, above all, regarded kindergarten and schools as important socialisation contexts. They expected these institutions to teach their children the skills and behaviours they were not able to teach themselves for various reasons, a lack of time being an obvious one.

Many parents stressed during the interviews that the children should be taught manners (for example, sitting still, showing respect), creative skills (handicrafts and drawing) and formal skills like maths, writing, reading, and foreign languages. According to several parents at that time, transmitting knowledge and rules of behaviour would be more efficient in kindergartens and schools than at home, like Ms. Hirtner pointed out in 2010 when asked what children can learn in school that they cannot learn at home: "Well, everything about relationships, I think they learn that better from outside of the family [...]. They learn social skills, they learn how to treat others".

Particularly during the first waves of the study, but also later on, the parents looked to kindergartens and schools to teach the use of different media, what we call media competences. If the parents were assuming that their children were still too young to deal with media, they viewed schools as the most important places for their children to gain media competence later.

For several children the nursery school or elementary school teachers were initially important as well. They acted as role models for social orientation, where there was no chance to learn that within their family. 
Later, we noted that children within socio-economically and socio-emotionally fraught families, like Viktoria Öllinger, but also Manfred Oblinger, tended to have equally fraught relationships to their teachers. They often could not get along with the teachers, felt misunderstood and pressured, so that several adolescents had a hard time at school. They perceived their everyday school life as a great burden while dealing with bad grades and worrying about having to resit a year. The struggles in school were often also a result of a lack of help with homework and projects at home, as well as a lack of funds to finance professional tutoring.

The adolescents-mainly boys-who got apprenticeships during the last wave of the study or the phone interview, mostly perceived this development as a positive and life-changing step towards their adulthood. Finishing compulsory school was a big relief, because the individual pressure to successfully complete school, while having to deal with personal problems within the family, was gone. Instead, they had a perspective of becoming productive within their apprenticeship. A very characteristic case in this context is Manfred Oblinger, who made an important contribution to the stressed socio-economic status of his family with the money he earned. He felt that he had no part of the family's problems anymore, but was nevertheless proud to support them. He wanted to leave the high school he attended in order to help the family financially, although it would have been an option to graduate and to pursue a college degree. Manfred suffered from losing his first apprenticeship-his position had unfortunately been terminated within the first three months. After his experience of failure, Manfred tried to cope with his disappointment by joining the online world again. He gained weight massively and showed first signs of a depression, just as his parents did. The apprenticeship in his desired branch, IT, has been a chance for him to prove his extensive knowledge and competences while feeling valuable and needed.

Other adolescents, who also got appropriate apprenticeships, felt their jobs led to strengthened competences for action and self-efficacy and they gained self-esteem from then on. Against this background, Mario Hirtner had to abandon his training to be an electrician because of his fear of heights, but he did receive a position within the IT sector after some preparation for it. Even the former socially isolated adolescents reported better social contacts, usually with their colleagues. They got along with them much better than with their classmates. And in addition, they declared the less influential position of their parents to be something fairly positive. 


\subsubsection{Assisted Living Communities and Apprenticeship Hostels}

Moving to assisted living accommodation did play a crucial role for some of the adolescents, and especially for Benedikt Holzner. These particular children received therapeutic treatment by social educators in such accommodation and could experience a structured daily routine, which was very different from their lives with the socio-economically and socio-emotionally burdened families.

The widespread prejudice over children in such facilities suffering negative consequences could not be confirmed in our results. Much rather, the facilities had a stabilising effect on the children's lives. For Benedikt Holzner, living there led to an enduring transformation, which showed itself in his strengthened resilience by the end of the study. He chose to continue living there, although he had already started his apprenticeship and was able to earn his livelihood. Through his caregivers, Benedikt experienced the attention, affection and closeness that he missed so desperately at home. He also displayed a positive development with regard to his excessive media use. The fixed daily routine and the supervision and regulation of his media use reflect on his use of media. Just like Benedikt Holzner, Timo Landinger also felt at ease at the facility, where therapeutic treatment and support was available for his, in fact, massive psychological problems. However, his release led to a regression in his development. Timo suffered not just because of his father's controlling behaviour and the latter's claim to be the sole contact person but also because of his father's psychological and physical violence aimed at casting out what he had learned in the facility. Timo has been left alone with his problems and was looking yet again for stress relief and self-assertion in violent computer games. Our study leads us to surmise that a prolonged residence in the facility would have been good for him.

\subsection{5 (Sports) Clubs}

According to the European Commission (2011), participation in sports is a policy goal in many countries, "because sport is regarded as an important vehicle for generating all kinds of social, psychological, health and academic effects" (Pot, Verbeek, van der Zwan, \& van Hilvoorde, 2016, p. 319). A lot of research has been conducted on the socio-economic differences and their effect on participation in sports activities (for example, see overview in Pot et al., 2016; see as well Dagkas \& 
Quarmby, 2012; Devís-Devís, Beltrán-Carrillo, \& Peiró-Velert, 2013; Kraaykamp, Oldenkamp, \& Breedveld, 2013). Most research shows that there are "vast differences in sport participation rates between children of lower and higher social classes" (Pot et al., 2016, p. 321) in general. Although sporting club membership is more common in higher SES groups, Pot et al. show "that if youngsters with a lower SES participate in organised sports, then the socialisation process is similar to that of youngsters with a higher SES" (Pot et al., 2016, p. 333). They conclude that parents are the key to participation in sports: "If they are able to provide a context in which sporting capital can be transmitted, chances are higher that children will (continue to) participate in sports, irrelevant of the SES of the parents. Nevertheless, differences in socio-economic contexts are very relevant when studying differences in participation rates between youngsters from lower and higher SES families" (Pot et al., 2016 , p. 333). This remarkable result also correlates with the findings of the Institut für Sozialforschung und Gesellschaftspolitik (IGS) from 2011 (see Engels \& Thielebein, 2011) about the relation of social class and participation in culture, education and leisure opportunities for children and adolescents, which were published in the Wealth Report of the Ministry of Work and Social Affairs of the Federal Republic of Germany. In relation to the results of the World Vision study 2010, it says: "the social background seems to be an essential factor, which is influencing the membership in a sports club. The class-specific analysis shows that only a third of the children of the lower class are active in a sports club, while it's $81 \%$ in the upper class. The authors of the World Vision Study explain that it is of high importance, with regard to drop-off in membership numbers, to make the access to these clubs as easy as possible for children of the lower class" (Engels \& Thielebein, 2011, p. 11). In the case of Austria, Einböck, Proyer, and Fenninger (2015) clearly show differences between young people threatened by poverty and other children or adolescents doing activities in leisure time, including sports or being a member in a sports club. Children who are not poor or threatened by poverty do, therefore, participate more frequently in sports.

From our panel, Helmut Pfortner was the only adolescent, who practised sport intensively and was member of a sports club. His family was in better socio-economic state from the third wave of the survey onwards. Benedikt Holzner and Alfons Weiss did sports as well-Alfons was, in fact, in a sports club when he was younger-but to a lesser extent. The vast majority of the panel was scarcely interested, or not at 
all, in sports. Two girls, Amelie Aufbauer and Simone Stab, were active in a sports club at the beginning, but, in case of Simone Stab, she herself abandoned this activity because of a lack of time, and in the case of Amelie Aufbauer, she gave up her sports activities for lack of money. One could clearly see the relation between the socio-economic resources of their families and their activity as a club member. Amelie's and Simone's families accessed only a few socio-economic resources during the survey.

The structure of the family has been identified as another essential factor. Accordingly, for children of single parents it was less common to be active in a sports club than other children-not least, because their parent was not able to support their child, for example by driving them to the sports club or picking them up after sports events or training, because of their day-to-day duties. Because of their burdened lives, the parents themselves weren't at all, or, at best, just occasionally, active in clubs or similar facilities and hadn't been able to direct their children in this direction.

\subsubsection{Politics and Society}

The political and societal context became more relevant in the socialisation of the adolescents compared to their early and mid-childhood, but not to the same extent as was the case with aspects of their lives described above. This became apparent in the attitude of many families towards neighbours with a migration background. Some families thought that the families with a migration background, especially the families with Turkish-Muslim origins, who lived in their areas, could be a threat to their children's socialisation. This was the case for the Grubert family and the Holzner family (in the first wave of the survey), the Aufbauer family (in the second wave), the Fein family (first wave) and the Tannhaus family (who withdrew after the second wave of the survey). They feared that their children would copy bad behaviour from the neighbourhood children with a Turkish background. For this reason, ${ }^{6}$ the parents of Manfred Oblinger did not allow him to have any contact with neighbouring children from a Turkish background at first. For some time, Manfred was convinced, despite his high-level intellect, that people with a migration background would take resources (welfare, jobs) away from families like his. He was the only adolescent interested in political topics from an early age. He has been enthusiastic about the now-deceased, populist right-wing politician, Jörg Haider. Manfred had 
the fantasy that Haider would close the borders for people with a migration background. The boy was strongly affected by Jörg Haider's sudden death in a car accident in the fall of 2008. He himself had planned to become a "Bundesheerlermann" [soldier of the Austrian Armed Forces, the authors] (second and fourth panel wave) to "be able to ensure order" in that role. Manfred was later very happy over Barack Obama's victory in the United States' elections, whom he saw in the position of an underdog as a black politician nevertheless displaying considerable success. During this period, Manfred fantasised of playing a similarly powerful role in his home country one day, as with Obama's presidency for the United States. Manfred had a Muslim friend for a period of time, during the fifth wave of the survey; as a result Manfred's mother builds a friendship with the boy's mother as well. During this period, so his mother, he had shown interest in Islam and he even sympathised with the "Islamic state" military for some time (fifth panel wave).

While most of the families had not shown any interest in political topics throughout the first five survey waves, apart from topics that had an immediate impact on their everyday lives, this changed in a sustained manner with the refugee crisis of 2015 and 2016, when they were confronted with the many refugees arriving in Austria. Refugees became a major topic in almost all families during the first period of the refugee crisis, and especially during the sixth wave of the survey. In order to better understand this issue, in the sixth wave of the survey we asked all families, parents and children, directly about their experiences with refugees, their attitudes and, in relation to that, the role of the media.

It stood out that those families socio-economically and/or socioemotionally strained saw the influx of refugees as threat and competition. On the one hand, they perceived the immediate proximity of their apartments to refugee accommodation as problematic. On the other hand, many parents perceived a feeling of competition, especially because of the financial and non-cash benefits, which the refugees received from the state and which they viewed as unjust. Many families had developed a fear for their livelihoods and viewed the payments to refugees as unjustified, because, in their eyes, the latter had never to contribute anything. The families also objected that refugees "had been given so much food" that they "would just throw it away", while they themselves had to "count the money" to make ends meet. Some parents mentioned critically that some refugees would "carelessly" stroll through their residential areas and leave much garbage behind. Some families with daughters 
and some girls related how they feared the many young, male Muslim refugees. They told of unpleasant and negative encounters, where they felt being gazed at and harassed. Fear was also generated through the massive media coverage of the events on New Year's Eve 2015-2016 in Cologne or through the social networks, where horror stories about refugees' behaviour purported to be facts. Friends and acquaintances also contributed negative experiences with refugees.

The adolescents learned about the refugee crisis through the intensive coverage in the media, especially through social media. Some of them were even annoyed by the constant flow of refugee-related information and tried to avoid it as far as possible. Others used YouTube and some bloggers on the topic to look for orientation and guidance. In general, adolescents as well as their parents regarded media coverage on this issue as suppressing or embellishing facts, and, therefore, as not credible. As they perceived the situation, public opinion condemned critical views on refugees as "racist" or "Nazi".

In addition to the media, the adolescents were confronted with the refugee issue through heated arguments in their families, and also as a daily topic at school. Some adolescents felt emotionally assailed, because of certain arguments they had with their teachers, who tried to explain the situation of refugees, in order to reach some kind of understanding with their pupils. Some children recounted how their schools had invited refugees to tell about their own experiences and their reasons for leaving their home country. This directly opposed the opinion in their families, who spoke mostly critically and negatively of refugees.

In a few families, mainly the families Dornbacher and Pfortner, we did not register resentments against people with a migration background, either among the parents or their children. These families expressed understanding towards the situation of these refugees who were driven out of their countries. Gudrun Dornbacher even actively got involved in the refugee relief.

\subsection{Conclusion}

This chapter discusses the core aspects of our longitudinal study over nearly twelve years. Our goal was to demonstrate how the dynamic development of the children and their media repertoires, on the one hand, and the role of different contexts of socialisation, such as parents, siblings, relatives and friends of the family, on the other hand, 
contributed to the children's socialisation. We could show how parents and children acted at different phases of their lives and which media services and media content they used, in order to make sense of everyday life. It became clear what the different ways looked like by which our subjects incorporated media, "established" as well as "new" ones. In this context, we identified the children's patterns of media usage and illustrated them by characteristic examples. These patterns underline how micro-structural factors, like age and gender, the specific developmental tasks and also their specific self-will, had an influence on the children's media usage. Media became particularly relevant for the children's lives if there were conflicts within the family.

Beyond that we shed light on the contexts of peers, friends and romantic partners, of kindergartens, schools and apprenticeships, as well as of assisted living communities and apprenticeship hostels. We discussed also how the young people participated in (sports)clubs-if they did at all-and what relevance sports had over the twelve years of the research. It became clear that only a few children did any sports at all. We discussed the role of politics and society by focusing on the question as to how our subjects-both parents and children-dealt with neighbours from a migration background and with the refugee crisis between 2015 and 2016. Most of them were scared of these people or afraid that they would get more support from the federal government of Austriasocial facilities and social services-than they themselves.

In this chapter, we have shown how different contexts become relevant in the process of socialisation. In the next chapter, we will focus on the direct interplay of two of these contexts, family and media. We will discuss this more deeply by looking into parents' mediation practices and how they can be interpreted against the background of the parents' and children's options for action, outlines for action and competences for action.

\section{Notes}

1. The original data is in German, all direct quotes that are used in this chapter were translated into English by the authors. In order to make the text more reader-friendly, we did not include such a reference for the individual quotes.

2. See Gebel, Schubert, Grimmeisen, and Wagner (2016). The authors also registered similar outcomes in the case of ten- to twelve-year-old YouTube users. 
3. In a new survey, Festl and Gniewosz (2017) analysed the role of parental strategies of media education with reference to new and digital media services and their importance for the family climate. They distinguished the relevance of what the parents' individually thought they could do. Festl and Gniewosz allude to the formal education of mothers and fathers: "The results confirmed that mothers and fathers with higher ICT parenting competence more often co-used the internet with their child, which was found to be a resource of positive family climate. With regard to the families' education background, we found the parents' co-use of ICTs was a signification mediator for the middle- and lower-educated families, precisely for lower-educated fathers" (Festl \& Gniewosz, 2017, p. 2).

4. Mario Hirtner, for example, allowed his little brother to play computer games which are actually forbidden to him. As a reward, he then demanded an Ice Tea from his brother. The siblings often met in Mario's room to watch funny YouTube videos. The little brother was one of a just a few social contacts beyond the internet.

5. See Kutscher's research (2014). She came up with similar results.

6. Gniewosz and Noack $(2015$, p. 1787) state that "during the past several decades, societies increasingly have become ethnically diverse. In this respect, developing attitudes toward immigrants or members of other social groups can be regarded as an important developmental task". Following this, they investigated negative aspects of intergroup attitudes, namely intolerant attitudes towards immigrants in Germany and focused on "the parent-adolescent transmission of attitudes towards immigrants between young people age 12 and 16". They summarise that "adolescents' attitudes were predicted by maternal and paternal self-reported attitudes".

\section{REFERENCES}

Chaudron, S., Beutel, M. E., Černikova, M., Donoso Navarette, V., Dreier, M., Fletcher-Watson, B., ..., Wölfling K. (2015). Young children (0-8) and digital technology: A qualitative exploratory study across seven countries. The EU Kids Online Network \& Joint Research Centre. London, UK and City of Luxembourg, Luxembourg: LSE and Publications Office of the European Union. Retrieved from http://publications.jrc.ec.europa.eu/repository/ handle/JRC93239.

Common Sense Media. (2015). Census media use by tweens and teens. San Francisco, CA: Common Sense Media. Retrieved from https://www. commonsensemedia.org/research/the-common-sense-census-mediause-by-tweens-and-teens. 
Common Sense Media. (2017). Census media use by kids age zero to eight 2017. San Francisco, CA: Common Sense Media. Retrieved from https://www. commonsensemedia.org/research/the-common-sense-census-media-use-bykids-age-zero-to-eight- 2017.

Couldry, N., \& Hepp, A. (2017). The mediated construction of reality. Cambridge, UK: Polity Press.

d'Haenens, L. (2001). Old and new media: Access and ownership in the home. In S. Livingstone \& M. Bovill (Eds.), Children and their changing media environment: A European comparative study (pp. 53-84). Mahwah, NJ: Lawrence Erlbaum Associates.

Dagkas, S., \& Quarmby, T. (2012). Young people's embodiment of physical activity: The role of the 'pedagogized' family. Sociology of Sport Journal, 29(2), 210-226.

Devís-Devís, J., Beltrán-Carrillo, V. J., \& Peiró-Velert, C. (2013). Exploring socio-ecological factors influencing active and inactive Spanish students in years 12 and 13. Sport, Education and Society, 20(3), 361-380.

Education Group. (2016). 5. Oö. Kinder-Medien-Studie 2016. Das Medienverbalten der 3- bis 10-Jäbrigen [Children and media in Upper Austria]. Linz, Austria: Education Group.

Einböck, M., Proyer, M., \& Fenninger, E. (2015). Lebensbedingungen und Sichtweisen von Kindern und Jugendlichen in und über Armut. Ergebnisse aus einer Erhebung zu den Lebenswelten und Netzwerken armutsbetroffener, armutsgefährdeter und nicht-armutsgefährdeter Kinder und Jugendlicher in zwei österreichischen Regionen [Living conditions and perspectives of children and adolescents in poverty, at risk to poverty and not at risk to poverty in two regions of Austria]. Projektberichte der Volkshilfe Österreich. Wien, Austria: Volkshilfe. Retrieved from https://www.volkshilfe.at/cms/download.php?downloadId $=348$ \&language $I d=1$.

Engelhardt, J. A. (2012). The developmental implications of parentification: Effects on childhood attachment. Graduate Student Journal of Psychology, 14, $45-52$.

Engels, D., \& Thielebein, C. (2011). Zusammenhang von sozialer Schicht und Teilnahme an Kultur-, Bildungs- und Freizeitangeboten für Kinder und Jugendliche [Coherences between social class and the participation in cultural, educational and recreational opportunities]. Köln, Germany: IGS Institut für Sozialforschung und Gesellschaftspolitik.

Erikson, E. H. (1950). Childhood and society. New York, NY: W. W. Norton.

European Commission. (2011). Developing the European dimension in sport. Brussels, Belgium: European Commission. Retrieved from http://eur-lex. europa.eu/LexUriServ/LexUriServ.do? uri=COM:2011:0012:FIN:en:PDF. 
Feierabend, S., \& Scolari, J. (2018). Was Kinder sehen. Eine Analyse der Fernsehnutzung Drei- bis 13-Jähriger 2017 [What children are watching on TV: An analysis of the TV usage of three- to 13-years-olds in 2017]. Media Perspektiven, 48(4), 163-175.

Feinberg, M. E., Sakuma, K.-L., Hostetler, M., \& McHale, S. (2013). Enhancing sibling relationships to prevent adolescent problem behaviors: Theory, design and feasibility of siblings are special. Evaluation and Program Planning, 36(1), 97-106.

Festl, R., \& Gniewosz, G. (2017, April 25-29). The role of mothers' and fathers' ICT parenting for family climate. Speech at the Annual Conference of the International Communication Association (ICA) in San Diego, CA.

Gebel, C., Schubert, G., Grimmeisen, L., \& Wagner, U. (2016). “... dieser YouTuber, der hat ganz krasse Maps bei Minecraft gefunden." YouTubeStars, Games und Kosten aus Sicht von 10- bis 12-Jährigen. Ausgewählte Ergebnisse der Monitoringstudie "Monitoring Aufwachsen zwischen Selbstbestimmung und Schutzbedarf” ["...this YouTube guy who found rad maps in Minecraft". YouTube stars, games and costs as perceived by ten- to twelve-year olds. Selected results of the monitoring-study. "Monitoring growing between self-determination and need for safety"]. ACT ON! Short Report Nr. 3. München, Germany: JFF. Retrieved from http://www.jff.de/jff/ aktivitaeten/von-a-z/projekt/proj_titel/act-on-monitoring.

Gniewosz, B., \& Noack, P. (2015). Parental influences on adolescents' negative attitudes toward immigrants. Journal of Youth and Adolescence, 44(9), 1787-1802.

Grundmann, M. (2000). Kindheit, Identitätsentwicklung und Generativität [Childhood, development of identity, and generativity]. In A. Lange \& W. Lauterbach (Eds.), Kinder in Familie und Gesellschaft zu Beginn des 21sten Jahrbunderts [Children in family and society at the beginning of the 21 st Century] (pp. 87-104). Stuttgart, Germany: Lucius \& Lucius.

Grüninger, C., \& Lindemann, F. (2000). Vorschulkinder und Medien. Eine Untersuchung zum Medienkonsum von drei- bis sechsjährigen Kindern unter besonderer Berücksichtigung des Fernsehens [Pre-school children and media: A study concerning media consumption among three- to six-years old children with a special focus on TV consumption]. Opladen, Germany: Leske und Budrich.

Harter, S. (2012). The construction of the self: Developmental and sociocultural foundations (2nd ed.). New York, NY: Guilford Press.

Havighurst, R. J. (1972). Development tasks and education. New York, NY: Longmans Green.

Koch, W., \& Frees, B. (2017). ARD/ZDF-Onlinestudie 2017: Neun von zehn Deutschen online [ARD/ZDF-Online study 2017: Nine out of ten Germans are online]. Media Perspektiven, 47(9), 434-446. 
Kraaykamp, G., Oldenkamp, M., \& Breedveld, K. (2013). Starting a sport in the Netherlands: A life-course analysis of the effects of individual, parental and partner characteristics. International Review for the Sociology of Sport, 48(29), $153-170$.

Krappmann, L. (1991). Sozialisation in der Gruppe der Gleichaltrigen [Socialisation among peers]. In K. Hurrelmann \& D. Ulrich (Eds.), Neues Handbuch der Sozialisationsforschung [New handbook on socialisation research] (pp. 355-375). Weinheim, Germany and Basel, Switzerland: Beltz.

Kutscher, N. (2014). Soziale Ungleichheit [Social inequality]. In A. Tillmann, S. Fleischer, \& K.-U. Hugger (Eds.), Handbuch Kinder und Medien [Handbook children and media] (pp. 101-112). Wiesbaden, Germany: VS Verlag für Sozialwissenschaften.

Larson, R. (2006). Positive youth development, willful adolescents, and mentoring. Journal of Community Psychology, 34(6), 677-689.

Lauricella, A. R., Cingel, D. P., Blackwell, C., Wartella, E., \& Conway, A. (2014). The mobile generation: Youth and adolescent ownership and use of new media. Communication Research Reports, 31(4), 357-364.

Li, S., Hietajärvi, L., Palonen, T., Salmela-Aro, K., \& Hakkarainen, K. (2017). Adolescents' social networks: Exploring different patterns of socio-digital participation. Scandinavian Journal of Educational Research, 61(3), 255-274.

Lillehammer, G. (2010). Introduction to socialisation: Recent research on childhood and children in the past. AmS-Skrifter, 23, 9-19.

May, V., \& Lahad, K. (2018). The involved observer: A simmelian analysis of the boundary work of aunthood. Sociology. First published January 2018. https://doi.org/10.1177/0038038517746051.

Morgan, E. M. (2012). Contemporary issues in sexual orientation and identity development. Emerging Adulthood, 1(1), 52-66.

MPFS (Medienpädagogischer Forschungsverbund Südwest). (2014). miniKIM-Studie 2014. Kleinkinder und Medien [miniKIM-Study 2014: Toddlers and the media]. Stuttgart, Germany: MPFS. Retrieved from https://www. mpfs.de/studien/minikim-studie/2014/.

MPFS (Medienpädagogischer Forschungsverbund Südwest). (2016). KIMStudie 2016. Kindheit, Internet, Medien. Basisstudie zum Medienumgang 6- bis 13-Jähriger in Deutschland [KIM-Study 2016: Childhood, internet, media]. Stuttgart, Germany: MPFS. Retrieved from https://www.mpfs.de/fileadmin/files/Studien/KIM/2016/KIM_2016_Web-PDF.pdf.

MPFS (Medienpädagogischer Forschungsverbund Südwest). (2017). JIM 2017. Jugend, Information, (Multi-)Media. Basisstudie zum Medienumgang 12- bis 19-Jähriger in Deutschland [JIM 2017: Adolescents, information, (multi-) media]. Stuttgart, Germany: MPFS. Retrieved from. https://www.mpfs.de/ fileadmin/files/Studien/JIM/2017/JIM_2017.pdf.

Notten, M., \& Kraaykamp, G. (2009). Parents and the media: A study of social differentiation in parental media socialization. Poetics, 37, 185-200. 
Ofcom. (2017). Children and parents: Media use and attitudes report. London, UK: Ofcom. Retrieved from https://www.ofcom.org.uk/research-and-data/ media-literacy-research/childrens/children-parents-2017.

Packer, M. J. (2017). Child development: Understanding a cultural perspective. London, UK, Los Angeles, CA, New Dehli, India, and Singapore: Sage.

Paus-Hasebrink, I., \& Bichler, M. (2008). Mediensozialisationsforschung. Theoretische Fundierung und Fallbeispiel sozial benachteiligte Kinder [Media socialisation research-Theoretical foundation and a case study on socially disadvantaged children]. Assisted by C. Wijnen. Innsbruck, Austria: Studienverlag.

Paus-Hasebrink, I., Schmidt, J.-H., \& Hasebrink, U. (2011). Zur Erforschung der Rolle des Social Web im Alltag von Heranwachsenden [Growing up with social web]. In J.-H. Schmidt, I. Paus-Hasebrink, \& U. Hasebrink (Eds.), Heranwachsen mit dem Social Web. Zur Rolle von Web 2.0-Angeboten im Alltag von Jugendlichen und jungen Erwachsenen [Growing up with social web: On the role of web 2.0 services in the everyday lives of adolescents and young adults] (2nd ed., pp. 13-40). Berlin, Germany: Vistas.

Paus-Hasebrink, I., Wijnen, C., \& Brüssel, T. (2011). Social Web im Alltag von Jugendlichen und jungen Erwachsenen: Soziale Kontexte und Handlungstypen [Social web in adolescent's and young adult's everyday life]. Assisted by U. Viieder. In J.-H- Schmidt, I. Paus-Hasebrink, \& U. Hasebrink (Eds.). Heranwachsen mit dem Social Web. Zur Rolle von Web 2.0-Angeboten im Alltag von Jugendlichen und jungen Erwachsenen [Growing up with social web: On the role of Web 2.0 services in the everyday lives of adolescents and young adults] (2nd ed., pp. 121-206). Berlin, Germany: Vistas.

Pot, N., Verbeek, J., van der Zwan, J., \& van Hilvoorde, I. (2016). Socialisation into organised sports of young adolescents with a lower socio-economic status. Sport, Education and Society, 21(3), 319-338.

Reitz, A. K., Zimmermann, J., Hutemann, R., Sprecht, J., \& Neyer, F. N. (2014). How peers make a difference: The role of peer groups and peer relationships in personality development. European Journal of Personality, 28(3), 279-288.

Rideout, V. J., \& Hamel, E. (2006). The media family: Electronic media in the lives of infants, toddlers, preschoolers and their parents. Menlo Park, CA: The Henry J. Kaiser Family Foundation. Retrieved from https://kaiserfamilyfoundation.files.wordpress.com/2013/01/7500.pdf.

Rideout, V. J., Vandewater, E. A., \& Wartella, E. A. (2003). Zero to six: Electronic media in the lives of infants, toddlers, preschoolers and their parents. A Kaiser Family Foundation Report. Menlo Park, CA: The Henry J. Kaiser Family Foundation. Retrieved from https://kaiserfamilyfoundation.files. wordpress.com $/ 2013 / 01 /$ zero-to-six-electronic-media-in-the-lives-of-infants-toddlers-and-preschoolers-pdf.pdf. 
Roberts, D. F., \& Foehr, U. G. (2004). Kids and media in America. Cambridge, UK: Cambridge University Press.

Rogers Hollifield, C., \& Jewsbury Conger, K. (2014). The role of siblings and psychological needs in predicting life satisfaction during emerging adulthood. Emerging Adulthood, 3(3), 143-153.

Schmidt, C. (2014). Die Bedeutung von Geschwistern für die soziale und kognitive Entwicklung von Kindern und Jugendlichen - Theorien und Forschungsbefunde [The importance of siblings for the social and cognitive development of children and adolescents-Theories and outcomes]. München, Germany: ifp Staatsinstitut für Frühpädagogik. Retrieved from http://www.familienhandbuch.de/familie-leben/familienformen/geschwister/diebedeutungvongeschwisternfuerdiesozialeundkogn.php.

Tarrant, M., MacKenzie, L., \& Hewitt, L. A. (2006). Friendship group identification, multidimensional self-concept, and experience of developmental tasks in adolescence. Journal of Adolescence, 29(4), 627-640.

Woodard, E. H., \& Gridina, N. (2000). Media in the home: The fifth annual survey of parents and children. Washington, DC and Philadelphia, PA: The Annenberg Public Policy Center of the University of Pennsylvania. Retrieved from https://www.annenbergpublicpolicycenter.org/wp-content/uploads/ survey72.pdf.

Youniss, J. (1980). Parents and peers in social development: A Sullivan-Piaget perspective. Chicago, IL: University of Chicago Press.

Open Access This chapter is licensed under the terms of the Creative Commons Attribution 4.0 International License (http://creativecommons.org/licenses/ by $/ 4.0 /$ ), which permits use, sharing, adaptation, distribution and reproduction in any medium or format, as long as you give appropriate credit to the original author(s) and the source, provide a link to the Creative Commons licence and indicate if changes were made.

The images or other third party material in this chapter are included in the chapter's Creative Commons licence, unless indicated otherwise in a credit line to the material. If material is not included in the chapter's Creative Commons licence and your intended use is not permitted by statutory regulation or exceeds the permitted use, you will need to obtain permission directly from the copyright holder.

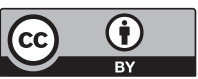

